Review Article

\title{
INTRODUCTION TO HYPERLIPIDEMIA AND ITS TREATMENT: A REVIEW
}

\author{
NIHARIKA VERMA \\ Department of Chemistry, Shri. J. N. P. G. College, Lucknow (U. P.) \\ Email: niharikaverma15@gmail.com \\ Received: 21 Sep 2016, Revised and Accepted: 15 Nov 2016
}

\begin{abstract}
Hyperlipidemia is a family of disorders that are characterised by abnormally high levels of lipida (fats) in the blood. While fats play a vital role in the body's metabolic processes, high blood levels of fats increase the risk of coronary heart disease (CHD). Cardiovascular diseases, especially coronary heart disease (CHD), are epidemic in India. According to American Heart Association, the Centres for Disease Control and Prevention, the National Institutes of Health and other government sources, cardiovascular disease is the leading global cause of death, accounting for more than 17.3 million deaths per year, a number that is expected to grow to more than 23.6 million by 2030. India has seen a rapid transition in its heart disease burden over the past couple of decades. Of the 30 million heart patients in India, 14 million reside in urban areas and 16 million in rural areas. If the current trend continues, by the year 2020, the burden of atherothrombotic cardiovascular diseases in India will surpass that of any other country in the world. The Registrar General of India reported that CHD led to 17\% of total deaths and 26\% of adult deaths in 2001-2003, which increased to 23\% of total and $32 \%$ of adult deaths in 2010-2013. The global increase in the prevalence of hyperlipidemia is due to unhealthy eating habits, obesity and physical inactivity. The emergencies, risk factors and remedies are described in the literature.
\end{abstract}

Keywords: Hyperlipidemia, Coronary heart disease, lipoproteins

(C) 2016 The Authors. Published by Innovare Academic Sciences Pvt Ltd. This is an open access article under the CC BY license (http://creativecommons.org/licenses/by/4.0/) DOI: http://dx.doi.org/10.22159/ijcpr.2017v9i1.16616

\section{INTRODUCTION}

Hyperlipidemia disease has afflicted humankind since antiquity. In 2002, coronay heart Epidemiological evidence strongly supported the positive correlation between blood lipids, hyperlipidemia and its complications, mainly CHD [1]. This relationship has been shown between and within cultures [2-4]. The hyperlipidemia is traditionally defined as conditions in which the concentration of cholesterol or triglyceride-carrying lipoproteins in plasma exceeds an arbitrary normal limit [5]. These lipoproteins deposit in the interstitial space of arteries arising from aorta, restricting the blood supply to the heart. This phenomenon is known as atherosclerosis. Higher deposition of lipoproteins completely blocked the blood supply to the heart, and thus myocardial infarction (MI) occurs, which is commonly known as heart attack.

\section{Cholesterol}

It is a vital component of the mammalian cell membrane of all tissues and is a precursor of steroid hormones and bile acids. It occurs, either free or as many fatty esters in all animal cells, but is absent in plant fats. Its structure is depicted in fig. 1.<smiles>CC(C)CCCC(C)C1CCC2C3CC=C4CC(O)CCC4(C)C3CCC12C</smiles>

Fig. 1: Structure of cholesterol

\section{Triglycerides}

These are the most abundant of all lipids. It is found abundantly in adipocytes. These are major components of storage fats in plant and animal cells. Excess calories, alcohol and sugar in the body get converted into triglycerides and stored in fat cells throughout the body [6]. Chemically triglycerides are esters of glycerol with 3 fatty acid molecules. The generic formula is shown in fig. 2. Data obtained from National Institute of Health, limits triglycerides value to 200 $\mathrm{mg} / \mathrm{dl}$ as the normal range and $500 \mathrm{mg} / \mathrm{dl}$ as an abnormal range. Range higher than $500 \mathrm{mg} / \mathrm{dl}$ is considered dangerous for the development of cardiovascular diseases [7].<smiles>[R]OCC(CO[R4])C(=O)O[R]</smiles>

Fig. 2: Structure of triglyceride (R1, R2, R3 = Alkyl group)

Lipoproteins: These are large globular particles that contain an oily core of nonpolar lipid (cholesteryl esters of triglycerides) surrounded by a polar coat of phospholipids free (i.e. unesterified) cholesterol and apoproteins. There are six classes of lipoproteins (table 1) that differ from one another in size, density and properties of triglycerides and cholesterol.

Table 1: Characteristics of major lipoprotein classes

\begin{tabular}{lll}
\hline Lipoprotein class & Density $(\mathbf{g} / \mathbf{m l})$ & Diameter (nm) \\
\hline Chylomicrons & $<<1.006$ & $500-80$ \\
VLDL & $<1.006$ & $80-30$ \\
IDL & $1.006-1.019$ & $35-25$ \\
LDL & $1.019-1.063$ & $25-18$ \\
HDL & $1.063-1.210$ & $5-12$ \\
Lp(a) & $1.055-1.085$ & 30 \\
\hline
\end{tabular}




\section{Chylomicrons}

These are the largest particles both in size as well as in density, and its concentration is directly correlated with dietary triglyceride contents.

VLDL: Very low-density lipoproteins are smaller particles carrying lesser triglyceride contents than chylomicrons, and are secreted from the liver. VLDL carries cholesterol from the liver to organ and tissues in the body. They are formed from the combination of cholesterol and triglycerides [8].

IDL: VLDL particles after degradation by lipase enzyme in the capillaries of adipose tissue and muscle give rise to intermediate density lipoprotein.

LDL: According to Lee et al., and Galeano et al., low-density lipoproteins are synthesised partly in intestinal chyle and partly after lipolysis of VLDL. It is directly correlated to $\operatorname{CHD}[9,10]$

HDL: HDL is commonly referred as good cholesterol. High-density lipoproteins are synthesised in the liver. It carries cholesterol and other lipids from tissues back to the liver for degradation [11]. HDL plays an antiatherogenic role.

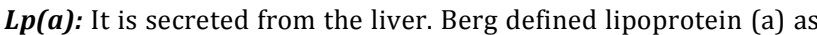
a cholesterol-rich plasma lipoprotein, which is directly correlated with atherosclerosis [12]. The risk of CHD is increased 2 to 5 fold with higher Lp(a) plasma concentration level.

Studies by Nago et al., concluded that Lp(a) levels were higher in females in contrary to males and statistically significant increase were observed in $\mathrm{Lp}(\mathrm{a})$ plasma level concentration with age. They also reported the lower $\operatorname{Lp}(\mathrm{a})$ plasma levels in alcohol drinkers, contrary to non-drinkers [13].

\section{Classification of hyperlipidemia.}

\section{On the basis of lipid type}

Hypercholesterolemia-In this the level of cholesterol is elevated.

Hypertriglyceridemia-It is defined as an elevated level of triglycerides.

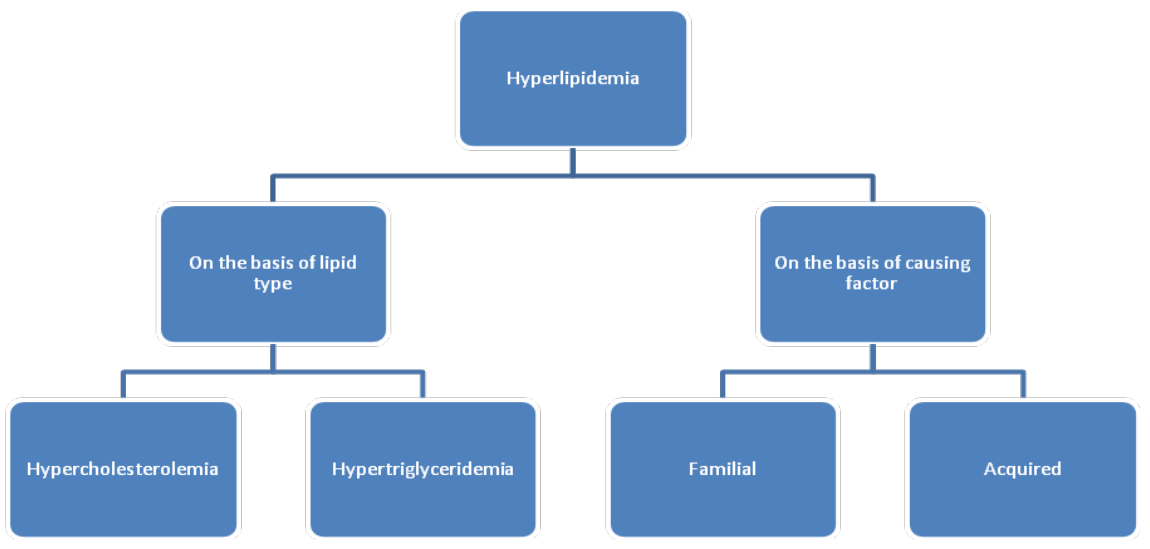

\section{On the basis of causing factor}

Familial (Primary) hyperlipidemia-On the basis of causing factors hyperlipidemia can be designated as either primary or secondary [14]. According to Fredrickson familial hyperlipidemia is classified into five types (table 2) on the basis of electrophoresis or ultracentrifugation pattern of lipoproteins [15].

- Type I-Raised cholesterol with high triglyceride levels.

- Type II-High cholesterol with normal triglyceride levels.
- Type III-Raised cholesterol and triglycerides.

- Type IV-Raised triglycerides, atheroma and uric acid.

- Type V-Raised triglycerides.

This classification was later adopted by WHO. This method does not directly account for HDL and also does not distinguish among the different genes that may be partially responsible for some of these conditions. It remains a popular system of classification but is considered dated by many [16].

Table 2: Fredrickson classification for hyperlipidemia

\begin{tabular}{|c|c|c|c|c|c|}
\hline $\begin{array}{l}\text { Hyperlipo- } \\
\text { proteinemia }\end{array}$ & Synonyms & Defect & $\begin{array}{l}\text { Increased } \\
\text { lipoprotein }\end{array}$ & Symptoms & Treatment \\
\hline Type I & $\begin{array}{l}\text { Familial } \\
\text { hyperchylomicronemia } \\
\text { Familial apoprotein CII } \\
\text { deficiency }\end{array}$ & $\begin{array}{l}\text { Decreased lipoprotein } \\
\text { lipase (LPL) } \\
\text { Altered ApoC2 }\end{array}$ & Chylomicrons & $\begin{array}{l}\text { Acute pancreatitis, lipemia } \\
\text { retinalis, xanthomas, } \\
\text { hepatosplenomegaly }\end{array}$ & Diet control \\
\hline \multirow[t]{2}{*}{ Type II } & $\begin{array}{l}\text { Familial } \\
\text { hypercholesterolemia }\end{array}$ & $\begin{array}{l}\text { LPL inhibitor in blood } \\
\text { LDL receptor } \\
\text { deficiency }\end{array}$ & LDL & $\begin{array}{l}\text { Xanthelasma, arcus senilis, } \\
\text { tendon xanthomas }\end{array}$ & $\begin{array}{l}\text { Bile acid } \\
\text { sequestrants, } \\
\text { statins, niacin }\end{array}$ \\
\hline & $\begin{array}{l}\text { Familial combined } \\
\text { hyperlipidemia }\end{array}$ & $\begin{array}{l}\text { Decreased LDL } \\
\text { receptor and } \\
\text { increased Apo B }\end{array}$ & LDL and VLDL & & $\begin{array}{l}\text { Statins, niacin, } \\
\text { fibrate }\end{array}$ \\
\hline Type III & $\begin{array}{l}\text { Familial } \\
\text { dysbetalipoproteinemia }\end{array}$ & $\begin{array}{l}\text { Defect in Apo E2 } \\
\text { synthesis }\end{array}$ & IDL & $\begin{array}{l}\text { Tuboruptive xanthomas and } \\
\text { palmar xanthomas }\end{array}$ & Fibrate, statins \\
\hline Type IV & $\begin{array}{l}\text { Familial } \\
\text { hypertriglyceridemia }\end{array}$ & $\begin{array}{l}\text { Increased VLDL } \\
\text { production and } \\
\text { decreased elimination }\end{array}$ & VLDL & $\begin{array}{l}\text { Can cause pancreatitis at high } \\
\text { triglyceride levels }\end{array}$ & $\begin{array}{l}\text { Fibrate, niacin, } \\
\text { statins }\end{array}$ \\
\hline Type V & & $\begin{array}{l}\text { Increased VLDL } \\
\text { production and } \\
\text { decreased LPL }\end{array}$ & $\begin{array}{l}\text { VLDL and } \\
\text { chylomicrons }\end{array}$ & & Niacin, fibrate \\
\hline
\end{tabular}


Acquired (Secondary) hyperlipidemia-Acquired hyperlipidemia (secondary dyslipoproteinemias) results from underlying disorders and lead to alterations in plasma lipid and lipoprotein metabolism [17]. This type of hyperlipidemia may mimic primary forms of hyperlipidemia and can have similar consequences. They may result in increased risk of premature atherosclerosis, pancreatitis and other complications of the chylomicronemia syndrome. The most common causes of acquired hyperlipidemia are given below [18].

- Diabetes Mellitus

- Use of drugs such as diuretics, $\beta$-blockers and estrogens.
- Alcohol consumption.

- Some rare endocrine disorders and metabolic disorders.

- Hypothyroidism

- Renal failure

- Nephrotic syndrome

Major primary and secondary forms of hyperlipidemia, their lipoprotein abnormalities and drugs used for their treatment are listed in table 3 and table 4.

Table 3: Common forms of primary hyperlipidemia

\begin{tabular}{lll}
\hline Disorder & Lipoprotein abnormality & Drug therapy \\
\hline Familial hypercholesterolemia & $\uparrow \uparrow$ LDL & Lovastatin \\
Familial defective apolipoprotein B & $\uparrow \uparrow L D L$ & None \\
Polygenic hypercholesterolemia & $\uparrow L D L$ & Lovastatin \\
Familial lipoprotein lipase deficiency & $\uparrow$ Chylomicrons & Nicotinic acid \\
Familial hypertriglyceridemia & $\uparrow$ VLDL & Gemfibrozil \\
Familial combined hyperlipidemia & $\uparrow V L D L, \uparrow L D L, \downarrow H D L$ & Nicotinic acid, clofibrate \\
Familial dysbetalipoproteinemia & $\uparrow$ Chylomicrons, $\uparrow L D L, \downarrow$ IDL, $\downarrow$ HDL & Gemfibrozil \\
\hline
\end{tabular}

Table 4: Common forms of secondary hyperlipidemia

\begin{tabular}{|c|c|c|}
\hline Condition & Lipid abnormalities & Lipoprotein abnormalities \\
\hline Diabetes mellitus & $\uparrow T G$ & $\uparrow$ VLDL, $\downarrow$ HDL \\
\hline Nephrotic syndrome & $\uparrow$ Chol & $\uparrow L D L$ \\
\hline Uremia & $\uparrow T G$ & $\uparrow V L D L, \downarrow H D L$ \\
\hline Hypothyroidism & $\uparrow$ Chol & $\uparrow L D L$ \\
\hline Obstructive liver disease & $\uparrow$ Chol & $\uparrow \operatorname{Lp}(\mathrm{a})$ \\
\hline Alcoholism & $\uparrow T G$ & $\uparrow V L D L$ \\
\hline Oral contraceptive & $\uparrow T G$ & $\uparrow V L D L, \downarrow H D L$ \\
\hline$\beta$-Adrenergic blocking agents & $\uparrow T G$ & $\uparrow V L D L, \downarrow H D L$ \\
\hline Isotretinoin & $\uparrow T G$ & $\uparrow$ VLDL \\
\hline
\end{tabular}

Several prospective studies have identified hypertension [19] higher concentration of lipids in serum [20-22] and cigarette smoking [23, 24] as the three treatable risk factors that have the highest association with CHD. The association of total plasma cholesterol levels (TC) with the incidence of CHD is well established $[25,26]$. The low-density lipoprotein cholesterol (LDL-C) is directly correlated [27-29], while high-density lipoprotein cholesterol (HDLC) is inversely related [30-32] to CHD incidence. Human plasma IDL$\mathrm{C}$ are a heterogeneous collection of particles which vary in buoyant density, size, lipid and protein composition $[33,34]$. The presence of estrogens in female lowers serum lipids [35].

\section{Complications of hyperlipidaemia}

I. Atherosclerosis: It is a common disorder and occurs when fat, cholesterol and calcium deposits in the arterial linings [36]. This deposition results in the formation of fibrous plaques. A plaque normally consists of three components: 1) atheroma which is a fatty, soft, yellowish nodular mass located in the centre of a larger plaque that consists of macrophages, which are cells that play a role in immunity; 2) a layer of cholesterol crystals; and, 3) calcified outer layer. Atherosclerosis is the leading cause of cardiovascular disease.

II. Coronary Artery Disease (CAD): Atherosclerosis is the major cause of CAD. It is characterised by the narrowing of the arteries that supply blood to the myocardium and results in limiting blood flow and insufficient amounts of oxygen to meet the needs of the heart. The narrowing may progress to the extent that the heart muscle would sustain damage due to lack of blood supply. Elevated lipid profile is correlated to the development of coronary atherosclerosis [37].

III. Myocardial Infarction (MI): MI is a condition which occurs when blood and oxygen supplies to the cardiac arteries are partially or completely blocked, resulting in damage or death of heart cells. The blockage is usually due to the formation of a clot in an artery.
This condition is commonly known as heart attack. The studies show that one-fourth of survivors of myocardial infarction were hyperlipidemic [38].

IV. Angina Pectoris: Angina is not a disease but a symptom of an underlying heart condition. It is characterised by chest pain, discomfort or a squeezing pressure. Angina occurs as a result of a reduction or a lack of blood supply to a part or the entire heart muscle. Poor blood circulation is usually due to CHD when partial or complete obstruction of the coronary arteries is present.

V. Ischemic stroke or Cerebrovascular Accident (CVA): It occurs when blood circulation in part of the brain is blocked or diminished. When blood supply, which carries oxygen, glucose, and other nutrients, is disrupted, brain cells die and become dysfunctional. Usually, strokes occur due to blockage of an artery by a blood clot or a piece of atherosclerotic plaque that breaks loose in a small vessel within the brain. Clinical trials revealed that lowering of LDL and total cholesterol by $15 \%$ significantly reduced the risk of first stroke [39].

\section{Causes of hyperlipidemia}

- A diet rich in saturated fat and cholesterol increases blood cholesterol and triglyceride levels.

- Other disorders as obesity, diabetes mellitus and hypothyroidism increase the risk of hyperlipidemia.

- Smoking and not exercising may lead to hyperlipidemia [40].

- Excessive use of alcohol also increases the risk of hyperlipidemia.

- Certain drugs as steroids and $\beta$-blockers may cause hyperlipidemia.

- Hereditary factor is also one of the common causes for hyperlipidemia. 
- In some cases hyperlipidemia occurs during pregnancy.

- Lipoprotein lipase mutations [41].

\section{Symptoms of hyperlipidemia}

Hyperlipidemia usually has no noticeable symptoms and tends to be discovered during routine examination for atherosclerotic cardiovascular disease $[42,43]$.

- Symptoms may include chest pain (angina), heart attack or stroke.

- When levels are exceedingly high, cholesterol may be deposited in tendons or just beneath the skin under the eyes.

- Swelling of organs such as liver, spleen or pancreas.

- Blockage of blood vessels in brain and heart.

- Higher rate of obesity and glucose intolerance.

- Pimple like lesions across the body.

\section{Pathogenesis of hyperlipidemia}

Cholesterol, triglycerides, and phospholipids are transported in the bloodstream as complexes of lipid and proteins known as lipoproteins. Elevated total and low-density lipoprotein (LDL) cholesterol and reduced high-density lipoprotein (HDL) cholesterol are associated with the development of coronary heart disease (CHD).
During the early stages of the hyperlipidemia, blood monocytes and platelets attach to a vessel wall at the sites of endothelial damage. The release of the mediators such as platelet derived groth factors leads to a proliferation of smooth cells in the intimal and medial lining of the vessel, collagen synthesis, cholesterol uptake and the beginning of the hyperlipidemic plaque results. Plaque ruptures are resulting in the acute syndromes of unstable angina, myocardial infarction and sudden cardiac death [44].

\section{Diagnosis of hyperlipidemia}

Hyperlipidemia typically shows no symptoms and can only be detected by a blood test. Screening for hyperlipidemia is done with a blood test called a lipid profile. According to National Cholesterol Education Program (NECP) screening [45] should start at age 20, and if the report is normal, it should be repeated at least every five years. Normal levels for a lipid profile $[46,47]$ are listed below (table 5).

\section{Prevention of hyperlipidemia}

- Low fats and cholesterol diet should be taken.

- $\quad$ Eat foods high in soluble fifer such as oats, beans and certain fruits.

- $\quad$ Exercise regularly to maintain a healthy weight.

Controllable lifestyle changes are the best way to fight hyperlipidaemia. But when lifestyle changes fail to control the disease then treatment with cholesterol-lowering drugs is required.

Table 5: Normal levels for a lipid profile

\begin{tabular}{llll}
\hline Lipids & Desirable value & Borderline & High risk \\
\hline Cholesterol & Less than $200 \mathrm{mg} / \mathrm{dl}$ & $200-239 \mathrm{mg} / \mathrm{dl}$ & $240 \mathrm{mg} / \mathrm{dl}$ \\
Triglycerides & Less than $140 \mathrm{mg} / \mathrm{dl}$ & $150-199 \mathrm{mg} / \mathrm{dl}$ & $200-499 \mathrm{mg} / \mathrm{dl}$ \\
HDL cholesterol & $60 \mathrm{mg} / \mathrm{dl}$ & $40-50 \mathrm{mg} / \mathrm{dl}$ & $\mathrm{Less}$ than $40 \mathrm{mg} / \mathrm{dl}$ \\
LDL cholesterol & $60-130 \mathrm{mg} / \mathrm{dl}$ & $130-159 \mathrm{mg} / \mathrm{dl}$ & $160-189 \mathrm{mg} / \mathrm{dl}$ \\
Cholesterol/HDL ratio & 4.0 & 5.0 & 6.0 \\
\hline
\end{tabular}

\section{Treatment of hyperlipidemia}

In 1987 the National Institute of Health (NIH) established the National Cholesterol Education Program (NCEP) to be directed by the Adult Treatment Panel (ATP) for the purpose of issuing information for health professionals and the general public concerning testing, evaluating, monitoring and treating hyperlipidemia. An important criterion of ATP guidelines is the development of treatment goals for hyperlipidemia based on patient's risk of CHD.

ATP recommends two methods of treatment:

1) Therapeutic lifestyle changes; 2) Drug therapy.

\section{Therapeutic lifestyle changes}

Diet modification, regular physical activity, smoking cessation, and weight reduction should be tried as initial treatment, especially in mild cases of hyperlipidemia and in persons without CHD or CHD risk equivalent and $<2$ risk factors. It should be kept in mind that when dieting, cholesterol intake is reduced. At the same time, production of cholesterol, especially by the liver, increases. It is recommended that the intake should be restricted to $25 \%-35 \%$ of energy intake and that saturated fatty acids make up less than $7 \%$ of energy intake and that cholesterol intake should be less than $200 \mathrm{mg}$ daily. The intake of plant sterol esters and soluble fibre is advisable. A healthy diet can result in $10 \%$ to $15 \%$ reduction of cholesterol blood level.

\section{Drug therapy}

High LDL, the presence of risk factors, and documentation of CHD should qualify initiating drug therapy along with TLC. Monotherapy has been shown to be effective in treating hyperlipidemia, but combination therapy may be required for a comprehensive approach. Current lipid-lowering drugs include statins, ezetimibe, bile acid sequestrants or bile binding resins, niacin, fibric acid derivatives, and plant sterols.

Medication specially designed to reduce blood cholesterol levels may be prescribed when dietary modifications prove inadequate. In rare patients with extremely high cholesterol levels, repeated removal of blood plasma may be recommended to lower blood cholesterol levels. Most people require lifelong treatment of hyperlipidemia with both lifestyle measures and medications.

\section{Pharmacological treatment}

Numbers of hypolipidemic drugs are available in the market for the treatment of hyperlipidemia. The existing hypolipidemic drugs are listed in table 6 . In 1975, the results of the Coronary Drug Project indicated that the drugs are relatively ineffective for preventing myocardial infarction in patients with preestablished CHD.

This project examined the effects of estrogens, D-thyroxin, clofibrate and nicotinic acid. The high-dose estrogens were discontinued in 1970 because of an increased number of fatal cardiovascular events without any indication of benefit.

The low-dose estrogens were discontinued in 1975 because of suggestion of an excess incidence of mortality from cancer. Dthyroxin was discontinued in 1971 because of increased mortality in this group [48]

\section{Ayurvedic treatment}

Ayurvedic medicine is one of the world's oldest medical systems. Ayurvedic therapeutics is based on the "laws" of nature. Its approach to health-care is based on understanding the interrelationship of body, mind and spirit. The aim of ayurveda medicine is to integrate and balance these elements to prevent illness and promote wellness through diet, nutrition, herbs, yoga, meditation and daily seasonal routines [49]. 
Table 6: Existing hypolipidemic drugs

\begin{tabular}{|c|c|c|c|c|}
\hline Class & Drug & Major effect & Dose & Side effects \\
\hline HMG Co A Reductase & Mevastatin & Lowers LDL-C concentration & $20-40 \mathrm{mg} /$ day orally & Depression, anxiety, indigestion \\
\hline \multirow[t]{3}{*}{$\begin{array}{l}\text { inhibitor } \\
\text { (fig. 3) }\end{array}$} & Lovastatin & Same as above & $40 \mathrm{mg} /$ day orally & $\begin{array}{l}\text { Headache, rashes, } \\
\text { gastrointestinal symptoms }\end{array}$ \\
\hline & Pravastatin & Same as above & 30 mg/day orally & Depression, anxiety, alopecia \\
\hline & Simvastatin & Same as above & $5-10 \mathrm{mg} /$ day orally & Memory loss, dyspenea \\
\hline \multirow[t]{7}{*}{ Fibrates (fig. 4) } & Clofibrate & Lowers serum TG. concentration & 2 gm/day orally & Nausea, diarrhoea, arthralgias \\
\hline & Gemfibrozil & Lowers plasma TG by $40-55 \%$ & $1.2 \mathrm{gm} /$ day orally & $\begin{array}{l}\text { Abdominal pain, nausea, } \\
\text { diarrhoea }\end{array}$ \\
\hline & Fenofibrate & $\begin{array}{l}\text { Lowers plasma LDL-C concentration } \\
\text { and rise HDL-C concentration }\end{array}$ & 2-5 gm/day orally & $\begin{array}{l}\text { Nausea, constipation, skin } \\
\text { rashes }\end{array}$ \\
\hline & Ciprofibrate & Same as above & 5 gm/day orally & Constipation, skin rashes \\
\hline & Benzafibrate & $\begin{array}{l}\text { Supresses endogenous chol and TG } \\
\text { synthesis }\end{array}$ & $5 \mathrm{gm} /$ day orally & Myalgia, diarrhoea, skin rashes \\
\hline & Simfibrate & Lowers Chol and TG concentration & 1.5 gm/day orally & Skin rashes, nausea, myalgia \\
\hline & Etofibrate & Lowers VLDL and LDL concentration & $900 \mathrm{mg} /$ day orally & Flushing \\
\hline Antioxidant (fig. 5) & Probucol & Lowers plasma Chol by $10-15 \%$ & $\begin{array}{l}250-500 \mathrm{mg} / \text { day } \\
\text { orally }\end{array}$ & $\begin{array}{l}\text { Flatulence, eosinophilia, } \\
\text { paresthesia }\end{array}$ \\
\hline \multirow{7}{*}{$\begin{array}{l}\text { Other lipid lowering } \\
\text { drugs (fig. 6) }\end{array}$} & Nicotinic acid & Lowers LDL-C concentration & 2-6 gm/day orally & Vomiting, dyspepsia \\
\hline & Neomycin & Same as above & $0.5-2 \mathrm{gm} /$ day orally & Malabsorption diarrhoea \\
\hline & $\beta$-Sitosterol & Same as above & 6 gm/day orally & Laxative effect, vomiting \\
\hline & Dextro Thyroxin & Lowers plasma LDL-C concentration & 1-2 gm/day orally & Serious cardiac toxicity \\
\hline & $\begin{array}{l}\text { Aminosalicylic } \\
\text { acid }\end{array}$ & Same as above & $2 \mathrm{gm} /$ day orally & Steatorrhea \\
\hline & Tiadenol & Lowers plasma Chol level & $1600 \mathrm{mg} /$ day orally & Nausea \\
\hline & Sorbinicate & Lowers Chol and TG plasma level & 800 mg/day orally & Malabsorption \\
\hline \multirow[t]{2}{*}{$\begin{array}{l}\text { Bile acid binding resins } \\
\text { (fig. 7) }\end{array}$} & Cholestyramin & $\begin{array}{l}\text { Binds bile acid resulting Chol } \\
\text { catabolism }\end{array}$ & $12-16 \mathrm{mg} /$ day & Nausea, indigestion \\
\hline & Colestipol & Lowers plasma LDL-C levels & $15-30 \mathrm{gm} /$ day orally & Nausea, constipation \\
\hline
\end{tabular}<smiles>[CH][C@@]12C(=CCC[C@@H]1OC(=O)C(C)(C)CC)C=C[C@H](C)[C@@H]2CCC1C[C@@H](O)CC(=O)O1</smiles><smiles>CC[C@H](C)C(=O)O[C@H]1C[C@H](O)C=C2C=C[C@H](C)[C@H](CCC(O)C[C@H](C)CC(C)=O)[C@]21C</smiles><smiles>CC[C@H](C)C(=O)O[C@H]1C[C@@H](C)C=C2C=C[C@H](C)[C@H](CCC3C[C@H](O)CC(=O)O3)[C@]21C</smiles>

Lovastatin<smiles>CCC(C)(C)C(=O)OC1CC(C)C=C2C=C[C@H](C)C(CCC3C[C@@H](O)CC(=O)O3)[C@H]2[C@H]1C</smiles>

Simvastatin

Fig. 3: HMG-CoA reductase inhibitor<smiles>Cc1ccc(C(=O)O[GaH2])c(OCCC(C)(C)C(=O)O)c1</smiles><smiles>CCOC(=O)C(C)(C)Oc1ccc(Cl)cc1</smiles>

Clofibrate 
<smiles>CC(C)(Oc1ccc(C2CC2(Cl)Cl)cc1)C(=O)O</smiles><smiles>CC(C)(CCCCCC(Br)(Br)c1ccccc1)Oc1ccc(CNC(=O)c2ccc(Cl)cc2)cc1</smiles><smiles>CC(C)(Oc1ccc(Cl)cc1)Oc1ccc(Cl)cc1</smiles>

Simf ibrate<smiles>CC(C)(Oc1ccc(C2CC2(Cl)Cl)cc1)C(=O)O</smiles>

Ciprofibrate<smiles>CCOC(=O)C(=O)c1cccnc1</smiles>

Fig. 4: Fibrates<smiles>CCCCOC(=O)OCCCCO</smiles>

Fig. 5: Antioxidant<smiles>O=C(O)c1cccnc1</smiles>

Nicotinic acid<smiles>Nc1ccc(C(=O)O)c(O)c1</smiles>

p-amino salicylic acid<smiles>CC(C)C(C)CCC(C)C1CCC2C3CC=C4CC(O)CCC4(C)C3CCC12C</smiles><smiles>NC(Cc1ccc(Oc2cc(I)c(O)c(I)c2)cc1)C(=O)O</smiles>

Dextrothyroxin

Fig. 6: Other lipid-lowering drugs 

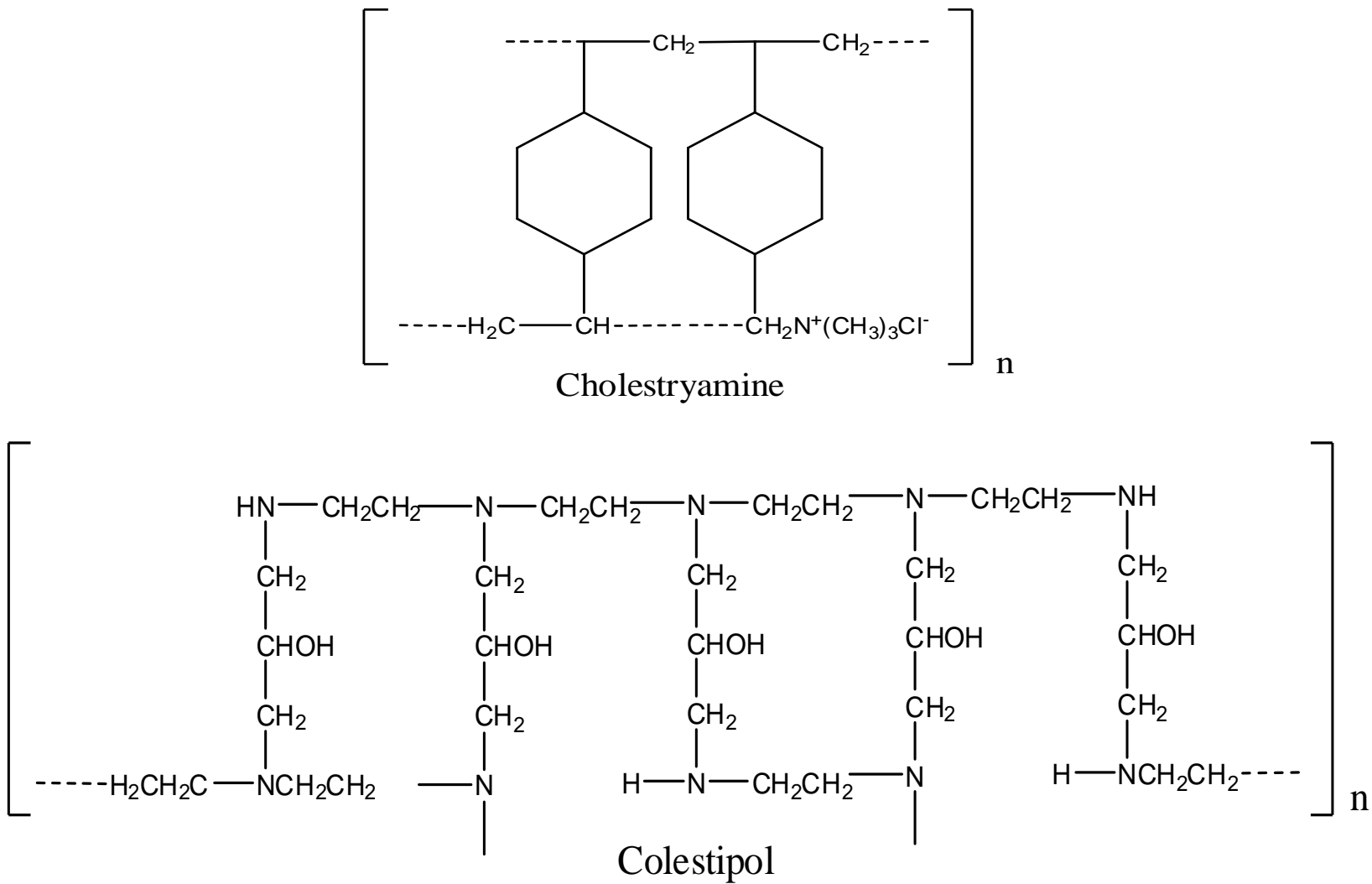

Fig. 7: Bile acid binding resins

There is no term for hyperlipidemia in Ayurveda. But distinct nomenclature is used, e. g., Rasagata Sneha Vriddhi (increased lipid plasma level), Rasa Raktagata Sneha Vriddhi (increased lipid plasma and lipid blood level), Medovriddhi (generalised lipid increase), Medoroga (obesity), AAMA Medo Dhatu (abnormally formed adipose tissue).

AAMA is the primary cause of all metabolic disorders in Ayurveda. A detailed study of hyperlipidemia reveals its similarity to Asthayi Medo Dhatu Vriddhi (abnormal increase in circulating lipids). This excessively increased circulating lipid is AAMA in nature, resulting in further complications [50].

Ayurvedic medicine has been used for thousands of years for treatment of various metabolic disorders. However, few studies have been conducted to evaluate the effectiveness of Ayurveda herbal medicine formulae on hyperlipidemia. Higher quality studies, such as randomised clinical trials, are lacking [51]. Some Ayurvedic herbs used in reducing the body cholesterol are listed in table 7 .

Table 7: Cholesterol reducing herbs

\begin{tabular}{lll}
\hline Herbs & Botanical name & Function \\
\hline Alfalfa & Medicago satina & Helps in clearing arteries congested with cholesterol. \\
Arjuna & Terminalia arjuna & It dissolves cholesterol in the coronary artery. \\
Coriander & Coriandrum sativum & It is diuretic in nature and flush out excess cholesterol from the body. \\
Garlic & Allium cepa & Reduces blood cholesterol level. \\
Guggulu & Commiphora mukul & Reduces blood cholesterol level. \\
Holy Basil & Ocimum sanctum & It dissolves the cholesterol accumulated in the arteries. \\
\hline
\end{tabular}

Ayurveda also prescribes "Yoga" as a beneficial tool for proper blood circulation and elimination of the cholesterol build up in the body [52]. Some of the useful asanas for the treatment of hyperlipidemia are-Ardhamatsyendrasana, Shalabhasana, Padmasana, Vajrasana.

\section{Home medications}

Besides, pharmacological and ayurvedic treatment, some home remedies are also beneficial in the treatment of hyperlipidemia.

Some home ingredients which help in lowering lipid and cholesterol level in the body are listed in table 8.

\section{Plants having hypolipidemic activity}

Medicinal plants have always been considered as a healthy source of life for all people due to its rich therapeutic properties and being $100 \%$ natural [53]. Medicinal plants are widely used by the majority of populations to cure various diseases and illness and have a high impact on the world's economy [54].

Over the past decade, herbal medicine has become a topic of global importance, making an impact on both world health and international trade. Continuous usage of herbal medicine by a large proportion in the developing countries is largely due to the high cost of Western Pharmaceuticals and Healthcare [55]. Medicinal plantbased drug industries is progressing very fast in India. The medicinal plants play a major role in hypolipidemic activity [56] The advantages of herbal medicines are effectiveness, safety, affordability and acceptability. Some plants having hypolipidemic property are listed in table 9. 
Table 8: Home remedies for dipping high cholesterol levels

\begin{tabular}{|c|c|}
\hline Ingradients & Role \\
\hline Nuts & Almonds lower LDL by $4.4 \%$, Walnuts lower LDL by $16 \%$. \\
\hline Oatmeal & Drops LDL by $12-24 \%$ \\
\hline Orange juice & Reduce blood cholesterol level. \\
\hline Coriander seeds & Lower cholesterol and triglycerides levels. \\
\hline Fish oil & Lower triglycerides levels. \\
\hline Honey & Lower cholesterol level. \\
\hline Soyabeans & Reduce the production of new cholesterol. \\
\hline Indian Gooseberry & Reduces excess cholesterol build-up. \\
\hline Brown Rice & Lower cholesterol level. \\
\hline Turmeric & Lowers LDL cholesterol levels. \\
\hline Brinjal & Lowers LDL cholesterol levels. \\
\hline Coconut oil & Increases HDL and improves the LDL/HDL ratio. \\
\hline Fenugreek seeds & Lowers cholesterol level by $14 \%$. \\
\hline Beans & Lowers LDL level \\
\hline Avocados & Lowers cholesterol level and boost up HDL level. \\
\hline Olive oil & Lowers LDL-C levels. \\
\hline Apples & Lowers cholesterol level. \\
\hline Broccoli & Lowers blood cholesterol level. \\
\hline Chocolate & Maintain HDL-C and reduces LDL-C levels. \\
\hline Barley & Lower blood cholesterol and triglyceride levels. \\
\hline Tomatoes & Lycopene lowers LDL-C level. \\
\hline Spinach & Lutein present prevents the cholesterol from sticking to the arterial wall. \\
\hline Yogurt & Reduces LDL level by $4 \%$. \\
\hline Beets & Checks the build-up of LDL. \\
\hline Green Tea & Lowers the cholesterol level. \\
\hline Margarine & Lower LDL level \\
\hline Ginger & Lower cholesterol level. \\
\hline Garlic & Reduces the formation of plaque in the blood vessels. \\
\hline Apple Cider Vinegar & Lower triglyceride level. \\
\hline
\end{tabular}

Table 9: Plants having hypolipidemic activity

\begin{tabular}{llll}
\hline Plant & Botanical name & Part used & Family \\
\hline Inca wheat & Amaranthus caudatus & Leaves \\
Palash & Butea monosperma & Leaves & Legume \\
Amaltas & Cassia fistula & Gum resin & Fabaceae \\
Guggul & Commiphora mukul & Flower & kernels \\
Kesraj & Eclipta alba & Bark & Asteraceae \\
Kalajam & Eugenia Jambolana & Root & Myrtaceae \\
Pipal & Ficus racemosa & Fruit & Moraceae \\
Mulethi & Glycyrrhiza glabra & Root & Leguminoceae \\
Bottle gourd & Lagenaria siceraria & Leaves, root, seed \\
Musli & Cholophytum borivilianum & Whole plant \\
Drumstick tree & Moringa oleifera & Pericarp \\
Snake jasmine & Rhinacanthus nasutus & & Liliaceae \\
Java jute & Hibiscus cannabinus & Moringaceae & Acanthaceae \\
\hline
\end{tabular}

\section{CONCLUSION}

The prevalence of hyperlipidemia, a major cause for coronary heart disease is very high in India. The relation between hyperlipidemia and occurrence of cardiovascular diseases has been already established. Various studies have reported the treatment of hyperlipidemic patients with antioxidants, fibrates, bile acid binding resins, etc.

Though many Ayurvedic formulations and herbal remedies are available to treat hyperlipidemia, the problem of enhanced cholesterol levels in the blood is still prevailing and is being a cause for many coronary disorders.

Recently, certain medicinal plants and herbs have seen light in treating these elevated lipid levels and reducing the risk of heart attacks. To reduce the risk of cardiovascular diseases due to hyperlipidemia requires urgent lifestyle intervention strategies and drugs that can reduce the cholesterol and triglyceride levels in the blood. Further studies are mandatory in order to provide more information about the safety and efficacy of novel antihyperlipidemic agents.

\section{CONFLICT OF INTERESTS}

Declared none

\section{REFERENCES}

1. Giorgio R, Francesco P, Rodalfo P, Duilio P. eds. Therapeutic selectivity and risk/benefit assessment of hypolipidemic drugs. Raven Press: New York; 1982.

2. Gordon DJ, Rifkind BM. Treating high blood cholesterol in older patient. Am J Cardiol 1989;63:48-52.

3. Jones PH. Lovastatin and simvastatin prevention studies. Am J Cardiol 1990;66:398-438.

4. Levy RI, Rifkind BM, Dennis BH, Ernst ND. Eds. Nutrition lipids and coronary heart disease, a global view. Raven Press: New York; 1979.

5. Goodman, Gilman. Eds. The pharmacological basis of therapeutics. Macmillan Publishing Company, New York; 1970.

6. Smelt AH. Triglycerides and gallstone formation. Clin Chim Acta 2010;411:1625-31.

7. Ginsberg HN, Goldberg IJ. Disorders of intermediary metabolism (Disorders of lipoprotein metabolism). In: Principles of Internal Medicine. 15 $5^{\text {th }}$ edition; 2001. 
8. Sundaram M, Yao Z. Recent progress in understanding protein and lipid factors affecting hepatic VLDL assembly and secretion. Nutr Metab 2010;27:35.

9. Ahmed SM, Clasen MD, Donnelly MD. Managment of dyslipidemia in adults. Am Family Physician 1998;57:1-16.

10. Costel P. Molecular pathways and agents for lowering LDLcholesterol in addition to statins. Pharmol Ther 2010;126:263-78.

11. Ridker PM, Genest J, Boekholdt SM, Libby P, Gotto AM, Nordestgaard BG, et al. HDL cholesterol and residual risk of first cardiovascular events after treatment with potent statin therapy: an analysis from the JUPITER trial. Lancet 2010;376:333-9.

12. Danesh J, Collins R, Thijs V. Lipoprotein (a) and stroke: a metaanalysis of observational studies. Stroke 2007;38:1959-66.

13. Sharpe PC, Young IS, Evans AE. Effect of moderate alcohol consumption on lp (a) lipoprotein concentrations. The reduction is supported by other studies. Br Med J 1998;316:1675.

14. Schonfeld G. Inherited disorders of lipid transport. Endocrinol Matab Clin North Am 1990;19:229-57.

15. Fredrickson DS, Lees RS. A system for phenotyping hyperlipoproteinemia. Circulations 1965;31:321-7.

16. Jain K, Kathivarin MK, Rahul S, Chamanlal J. The biology and chemistry of hyperlipidemia. Bioorg Med Chem 2007;15:4674-99.

17. Chait A, Brunzell JD. Acquired hyperlipidemia (secondary dyslipoproteinemias). Endocrinol Metab Clin North Am 1990;19:259-78.

18. Stone NJ. Secondary causes of hyperlipidemia. Med Clin North Am 1994;78:117-41.

19. Fries ED. Hypertension and atherosclerosis. Am J Med 1969;46:735-40.

20. Brown DF, Kinch SH, Doyle JT. Serum triglycerides health and in ischemic heart disease. New Eng J Med 1965;273:947-527.

21. Gofman JW, Young W, Tandy R. Ischemic heart disease, atherosclerosis and longevity. Circulation 1966;34:679-97.

22. Page IH, Stamler J. Diet and coronary heart disease. Mod Concepts Cardiovasc Dis 1968;37:119-30.

23. Auerbach 0, Hammond EC, Garfinkel L. Thickening of walls of arterioles and small arteries in relation to age and smoking habits. New Eng J Med 1968;278:980-4.

24. Selzer CC. An evaluation of the effect of smoking on coronary heart disease. J Am Med Assoc 1968;203:1193-2001.

25. Keys A, Kimura NK, Kusukawa A, Bronte-Stewart B, Larson N, Keys MH. Lessons froum serum cholesterol studies in Japan, Hawaii and Los Angles. Ann Intern Med 1958;48:83-94.

26. Keys A, Aravanis C, Blackburn H, Vann B, Buzina R, Djordjevic $\mathrm{BS}$, et al. Coronary heart disease, overweight and obesity as risk factors. Ann Intern Med 1972;77:15-27.

27. Kannel WB, Castelli WP, Gordon T, McNamara PM. Serum cholesterol, lipoprotein and the risk of coronary heart disease. Ann Intern Med 1971;74:1-12.

28. Carlson LA, Bittiger LE. Ischemic heart disease in relation to fasting values of plasma triglycerides and cholesterol. Lancet 1972;1:865-68.

29. Albrink MJ, Meiges WJ, Man EB. Serum lipids, hypertension and coronary artery disease. Am J Med 1961;31:4-23.

30. Avogaro P, Cazzolato G. Familial hyper-HDL- $(\alpha)$ cholesterolemia. Atherosclerosis 1975;22:63-7.

31. Gorden T. High-density lipoprotein as a protective factor against coronary heart disease. Am J Med 1977;62:707-14.

32. Heiss $\mathrm{G}$. The epidemiology of plasma high-density lipoprotein cholesterol levels. Circulation 1980;62:116-36.

33. Adams GH, Schumaker VN. The polydispersity of human low density lipoproteins. Ann NY Acad Sci 1969;164:130-46.

34. Shen MS, Krauss RM, Lindgren FT, Forte TM. Heterogeneity of serum low-density lipoproteins in normal human subjects. J Lipid Res 1981;22:236-44.
35. The coronary drug project. Findings leading to discontinuation of the $2.5 \mathrm{mg} /$ day estrogen group. J Am Med Assoc 1973;226:652-7.

36. Wouters K, Shiri-Sverdlov R, Van Gorp PJ, Van Bilsen M, Hofker $\mathrm{MH}$. Understanding hyperlipidemia and atherosclerosis: Lessons from genetically modified apoe and ldlr mice. Clin Chem Lab Med 2005;43:470-9.

37. Gao W, He HW, Zhao H, Xiao-Qing Lian XQ, Wang YS, Zhu J, et al. Plasama levels of lipometabolism related miR-122 and miR-370 are increased in patients with hyperlipidemia and associated with coronary artery disease. Lipids Health Dis 2012;11:55.

38. Nickolas TL, Radhakrishnan J, Appel GB. Hyperlipidemia and thrombotic complications in patients with membranous nephropathy. Semin Nephrol 2003;23:406-11.

39. Amarenco P, Labreuche J. Lipid management in the prevention of stroke: review and updated meta-analysis of statins for stroke prevention. Lancet Neurol 2009;8:453-63.

40. Gupta R, Mohan I, Narula J. Trends in coronary heart disease epidemomiology in India. Ann Global Health 2016;82:307-15.

41. Keane WF, Peter J, Kasiske BL. Is the aggressive management of hyperlipidemia in nephrotic syndrome mandatory. Kidney Int 1992;38:134-41.

42. Bhatnagar D, Soran H, Durrington PN. Hypercholesterolaemia and its management. Br Med J 2008;337:993.

43. Grundy SM, Balady GJ, Criqui MH. Primary prevention of coronary heart disease. Circulation 1998;97:1876-7.

44. Scott J. Trends in the therapy of hyperlipidemia. Drugs Today 1991;27:223-8.

45. National cholesterol education program: Second report of the expert panel on detection, evaluation and treatment of high blood cholesterol in adults. Circulation 1994;89:1333-445.

46. AAFP. Endocrine Society releases guidelines on diagnosis and management of hyperglyceridemia. Am Fam Physician 2013;88:142-4.

47. Adopted from "Export panel on integrated guidelines for cardiovascular health and risk reduction in children and adolescents: Summary report". Pediatrics 2011;128:1-72.

48. The coronary drug project.: Clofibrate and niacin in coronary heart disease. J Am Med Assoc 1975;231:360-81.

49. Tarabilda EF. Ayurveda revolutionised. Lotus Press: India; 1998.

50. Manjiri AN, Vyas SN, Baghel MS, Ravishanker B. Randomized placebo-controlled trial of mustadi ghanavati in hyperlipidemia. AYU 2010;31:287-93.

51. Singh BB, Vinjamury SP, Der-Martirosian C, Kubik E, Mishra LC, Shepard N, et al. Ayurvedic and collateral herbal treatments for hyperlipidemia: a systematic review of randomised controlled trials and quasiexperimental designs. Alternative Ther Health Med 2007;13:22-8.

52. Shantakumari N, Sequeira S, EL deeb R. Effects of a yoga intervention on lipid profiles of diabetic patients with dyslipidemia. Indian Heart J 2013;65:127-31.

53. Edeoga HO, Okwu DE, Mbaebie BO. Phytochemical constituents of some Nigerian medicinal plants. Afr J Biotechnol 2005;4:685-8.

54. Bauman AE. Updating the evidence that physical activity is good for health: an epidemiological review 2000-2003. J Sci Med Sport 2004;7:6-19.

55. Cunningliam AB. An investigation of the herbal medicine trade in Natal/Kwa Zulu. Investigational Report No: 29, Institute of Natural Resources, University Natal, Pietermaritzburg; 1988.

56. Muramatsu K, Fukuyo M. Effect of green Tea catechins on plasma cholesterol level in cholesterol feed rats. J Nutr Sci Vitaminol 1986;56:509-20.

\section{How to cite this article}

- Niharika Verma. Introduction to hyperlipidemia and its treatment: a review. Int J Curr Pharm Res 2017;9(1):6-14. 